Article

\title{
Estimation of Peak Discharge in a Poorly Gauged Catchment Based on a Specified Hyetograph Model and Geomorphological Parameters: Case Study for the 23-24 October 2008 Flood, KALAYA Basin, Tangier, Morocco
}

\author{
Iliasse Khaddor ${ }^{1, *}$, Mohammed Achab ${ }^{2}$, Abdelkader Ben jbara ${ }^{3}$ and Adil Hafidi Alaoui ${ }^{1}$ \\ 1 Department of physics, Faculty of Science and Technics, Abdelmalek Essaâdi University, \\ 90010 Tangier, Morocco; pr_alaoui@yahoo.fr \\ 2 Department of Earth Sciences, Scientific Institute, Mohammed V University of Rabat Morocco, \\ 10010 Rabat, Morocco; achab.mohammed@uca.es \\ 3 Direction de l'Hydraulique, 93000 Tétouan, Morocco; benjebaray@yahoo.fr \\ * Correspondence: ilias.khaddor@gmail.com; Tel.: +212-6-82490182
}

Received: 13 December 2018; Accepted: 18 January 2019; Published: 21 January 2019

\begin{abstract}
The determination of discharge from stage measurement is an essential procedure in surface hydrology. Due to limited data availability in terms of discharges and rainfalls, a number of non-flood water levels have been used for deriving a rating curve based on an indirect method with specific cross-sections, longitudinal slope of the river, and bed roughness at the KALAYA gage station. In addition, instantaneous rainfall recordings across the Meloussa gage station are available from 23 October 2008 storm event that have been collected in order to develop temporal distribution (hyetograph). Thereby, it provides the necessary input to generate a continuous rainfall-runoff time series, with the derived instantaneous discharge allowed us to calibrate the simulated stage-discharge hydrograph that covers the entire time of the storm event period from 23 to 24 October. An empirical equation was derived in order to provide the peak flow as a function of the given rainfall quantities, its standard deviation, and its standard deviation error. As a result, a very positive correlation between Runoff and Rainfall was observed with values of 0.999. Additional tests were performed to generate a peak discharge of approximately $486 \mathrm{~m}^{3} / \mathrm{s}$, using the observed hyetograph and calibrating $\mathrm{CN}$, Lagtime, and Initial abstraction. The results would improve the quality of the model since it allows for a more precise hyetograph to be simulated over a smaller area.
\end{abstract}

Keywords: rating curve; stage-discharge; specified hyetograph; KALAYA watershed; Tangier-Morocco

\section{Introduction}

Flooding is a devastating natural threat, which impacts different regions across the world every year. In fact, it is a recurrent problem in several densely populated Moroccan cities. They frequently result in considerable damage and, sometimes, in loss of life [1]. Most floods in Tangier city (Figure 1) are caused by torrential rain, which is characterized by its great volume and short duration due to the rugged topography of the study area. These floods affect larger areas due to the rapid urbanization of the river flood plain. On the other hand, most of the flash floods causing storms are poorly recorded by using conventional rain-gauge networks [2]. Meanwhile, the lack of the inability of managing this phenomenon is mainly caused, in most flash-storm cases, by the disability of not knowing the rain accumulations and the discharges over most of the watersheds of concern [3]. In terms of a lack of 
field flow data, the calculation of discharges can be based on the estimation of the peak flow from a defined cross-section if its geometry and hydraulic characteristics with the water level are available [4].

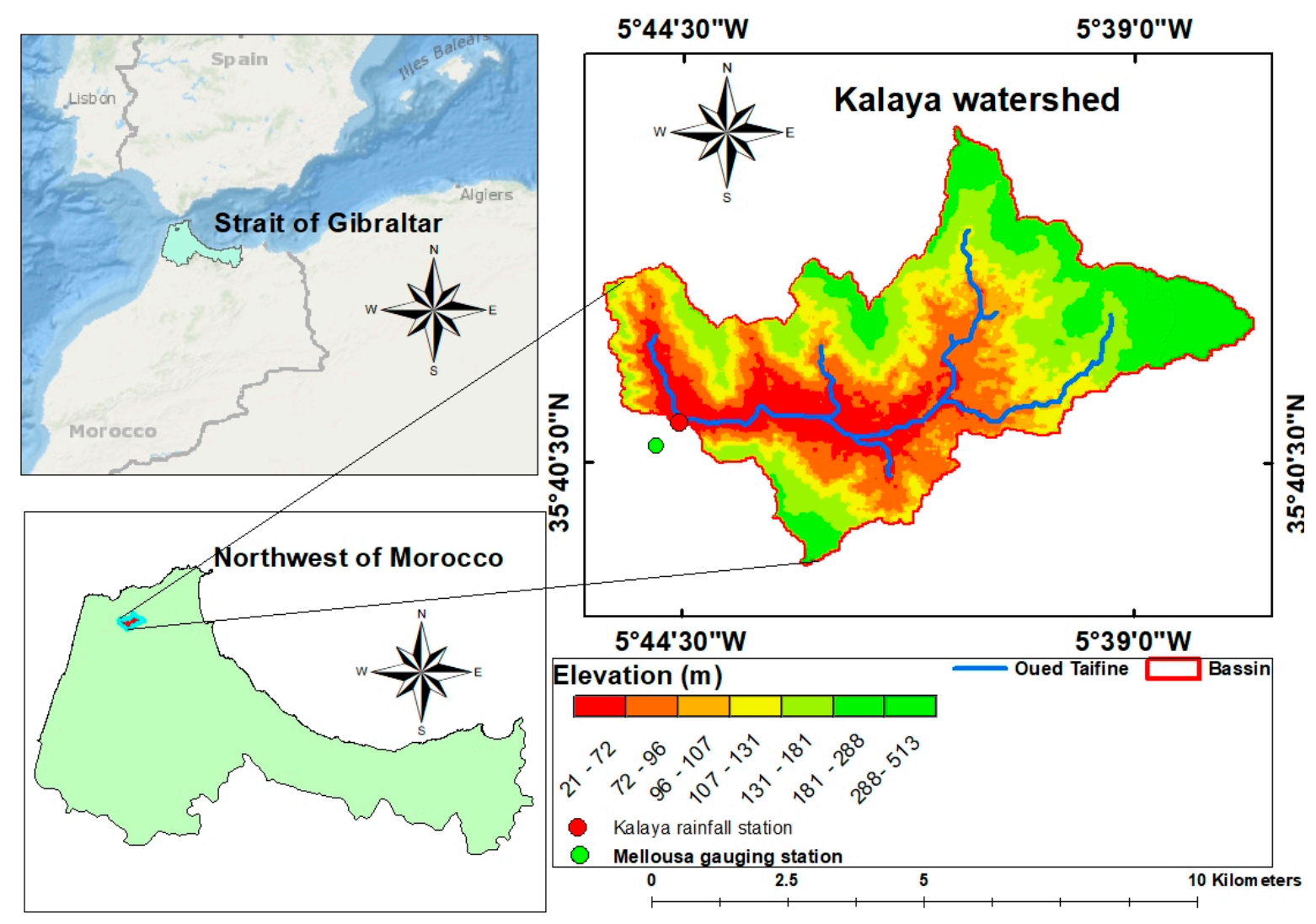

Figure 1. Location and digital elevation model (DEM) of the study area.

Direct current meter measurements are rarely available for extreme flash floods [5]. However, to save cost and time, the estimation of the stream discharge is typically calculated by transforming the recorded river stage data to discharge by using an estimated stage-discharge relationship [6,7]. Discharge does not depend on the stage alone. It is also a function of longitudinal slope of river, geometry of the specific cross-section, and the Manning coefficient [8].

Peak discharges are generally calculated using indirect methods such as the slope-area technic. These technics are based on empirical hydraulic formula, such as Manning's equation, based on water level observations during flash floods. However, the selection of the hyetograph is necessary for managing floodplains [9]. For example, Huff [10] performed hyetographs for extreme storms, which were presented in probability terms to provide reliable estimates of flows and general characteristics of the temporal rainfall distribution.

Gaume et al. [11] documented historical archives in flood analysis and reconstruction utilized for 550 flash flood events in seven European countries. Peak discharge data was collated for a number of past flash floods via post-flood surveys that used indirect methods. These events include Manning-Strickler formula estimation, extrapolation of calibrated stage-discharge relation, and hydraulic 1D and 2D simulation.

Graef \& Haigis [12] have developed the spatial and temporal rainfall distribution in a semi-arid Niger climate. They demonstrated, with varying time scales, the variability of that rainfall within short distances (a few kilometers). Stream gage recorded rainfall data for southwest Niger and showed that annual differences of 200-300 mm may occur within a radius of $100 \mathrm{~km}$.

An approach to establish a river rating curve from flood marks and historical accounts is discussed. A graph of the stage versus discharge known as a rating curve is shown [13]. The rating curve is 
among the most common methods used in discharge calculation. Hence, to predict the discharge from a recorded stage, there should be a specified relation between them. Therefore, to take in place the accurate relationship between the discharge and the stage, discharge is needed to indicate the dependency with the river stage. The river stage is the height of water surface above a nearby reference point [14]. The classical rating curve based on the river stage and the instantaneous discharge data utilizes the river stage as a function of the discharge at a specific cross-section [15]. Various techniques have been developed in order to study flash floods in a poorly gauged watershed. Dottori et al. [16] presented the improvement in the discharge computation. They stated a dynamic stage-discharge relationship for indirect discharge estimation, based on instantaneous water level measurements at two adjacent cross-sections. The determination of the rating curve has been made by converting the instantaneous water stages into instantaneous discharge under steady-flow conditions. Chatchai et al. [17] presented an estimation method based on a survey of stream geometry and the observed rating curve at a gauging station in the Upper Ping River catchment in Northern Thailand. By providing the channel geometry, slope, and the Roughness Manning, adapting the simulated rating curve to the observed one was made.

Goodrich et al. [18] concluded that the appropriate interval of the rainfall distribution for arid and semi land watersheds depends on many factors including the spatial-temporal pattern between the rainfall intensity, watershed response time, and infiltration characteristics. They recommended that rainfall intensity time increments for watersheds are preferred for use with equilibrium times smaller than $15 \mathrm{~min}$, but a maximum interval of $5 \mathrm{~min}$ should be used for more slowly responding basins.

River stages are relatively easy to measure as compared to the measurement of discharge. However, the discharges at a particular river cross-section can be directly measured through the means of the velocity-area method [19]. Following this, stream gage records are available for estimating design flows at KALAYA upstream sites. With variations in cross sections and bed slopes, these sites are only a small fraction of the number of potential bridge and culvert locations where design flow estimates might be required [20,21]. The KALAYA Basin (about $37 \mathrm{~km}^{2}$ ) in Tangier city, Morocco, is the field of this research because it contains a gauge station, which provides instantaneous discharges and rainfalls. At the KALAYA station, a "jaugeage au moulinet" instrument had been used to measure the depths in the downstream section.

\section{Study Area}

The KALAYA watershed subject of this study was chosen to calibrate the rainfall-runoff hydrological modeling for the region of Tangier (Figure 1). The KALAYA watershed is a tributary of Oued Mharhar and is included in the great basin of Tangiers in North Morocco. Compared to the geographical location of Tangier city, KALAYA basin is located in the southern part and it covers an area of $37.3 \mathrm{~km}^{2}$. The length of the main river is $20 \mathrm{~km}$ with an altitude of $513 \mathrm{~m}$ above the main sea level and the maximum slope is $35.97^{\circ}$. The average annual rainfall in the region is $720 \mathrm{~mm}$.

\section{Materials and Methods}

In the KALAYA watershed, the construction of the stage-discharge curve of extreme flash flood discharges was based on multidisciplinary data. Using the instantaneous discharges and rainfalls data at KALAYA and Roman gauging stations, the channel cross section geometry and the Manning's equation, the construction of the stage-discharge curve at the downstream cross sections could be made for limiting the probability of possible over-estimates of peak flows. Following this, the results of the models offer a reliable tool to be used in the management of watersheds. HEC-HMS is designed to simulate the rainfall-runoff processes of watershed systems to identify drainage and forecasting flood based on the resulted hydrograph. The physical representation of a watershed is made with the basin model. Yet, hydrologic elements (sub-basin, reach, junction, reservoir, diversion, source, and sink) are connected in a dendritic network to simulate runoff processes [22]. The second class (geomorphologic) are useful according to the SCS model to preliminary identify flooded areas. The DEM used in this work 
is obtained from the The Advanced Spaceborne Thermal Emission and Reflection Radiometer dataset (ASTER-DEM), which is a remotely sensed elevation data product at a horizontal spatial resolution of $30 \mathrm{~m}$. From a previous study on the KALAYA Basin [23], land cover was generated through ERDAS IMAGINE 9.3 software to produce land use classification by the mean of the multispectral image satellite Spot 5 (launched on 09 November 2005) at a resolution of $2.5 \mathrm{~m}$. Regarding the soil type classification, it was derived from the pedologic map of the region to represent different soil categories that describe the Hydrological Soil Group (HSG) required with land use for computing the Curve Number (CN). The soil map and the hydrologic soil group map were prepared, according to soil characteristics mentioned in pedological and geotechnical map of Tangier city. The land is approximately covered by $30.74 \%$ of the urban area, $19.08 \%$ of the bare soil, $11.18 \%$ of the agriculture, and $39.01 \%$ of the forest land, while the predominantly loamy clay consists almost $60 \%$ of the total soil types [23].

\subsection{Analysis of Rainfall Data}

The meteorological component is the first computing element by means of which the entry of precipitation is spatially and temporally distributed over the entire surface of the studied basin. The model requires precipitation and flow data with the accumulated depths over a 10-min duration. Thus, this module can be used to model evapotranspiration and snow. For the modeling of short duration rainfall-runoff events, evapotranspiration is often neglected [24,25]. The flooding on 23 October 2008 was chosen as the reference event in which all hydrological and hydraulical simulations were based in Tangier city. The entry of rainfall data to run the base model of the studied event will be the hyetograph, which describes the instantaneous distribution of the rainfall during the event over time. It was obtained as a historical record in the hydrometric station Melloussa in the roman basin by a rain gauge. It is also known as the regional synthetic rainstorm for Northern Tangier using established distributions and amounts of historical rainfall. The rain gage used in this study is located between $35^{\circ} 38^{\prime}$ and $35^{\circ} 44^{\prime}$ north latitude and $5^{\circ} 38^{\prime}$ and $5^{\circ} 47^{\prime}$ east longitude.

The determination of a storm hyetograph requires historic data recorded as continuously as possible [26]. It is at the Melloussa station, located to the east of the KALAYA watershed that the largest rainfall cumulation was recorded, with $214 \mathrm{~mm}$ between 03:30 Am to (local time) on the 23 October 2008 and $02: 00$ on the 24 October 2008.

The counting of this record makes it possible to represent the evolution of the maximum intensity of rainfall recorded in $10 \mathrm{~min}$. The rainy episode decomposes in two sequences (Figure 2): regular rains in the evening of 22 October 2008 with a cumulative $25 \mathrm{~mm}$ in $8 \mathrm{~h}$ followed by a peak of intensity of $133.1 \mathrm{~mm}$ in $7 \mathrm{~h}$. In the morning of 23 October 2008 between at $11: 40 \mathrm{~h}$ and $18 \mathrm{~h} 40 \mathrm{~min}$ then from $18 \mathrm{~h}$ $50 \mathrm{~min}$ to $23 \mathrm{~h} 20 \mathrm{~min}$, it was recorded a total of $55.9 \mathrm{~mm}$ over $6.5 \mathrm{~h}$. The recorded amount of rainfall is presented in probabilistic terms as cumulative precipitation depth. Regarding the time distribution of rainfall, durations of $4,8,12,16,20$, and 24 storms were selected. A few of these incremental times represent convective thunderstorms, especially those of durations of 12 and $16 \mathrm{~h}$. They clearly show that rain depths are increasing and have higher flow accumulation values. For $7 \mathrm{~h}$ of time distribution of rainfall distributions, cumulative depths demonstrated high variability precisely in the middle of the duration storm, as illustrated in Figures 2 and 3. Figure 3 represents the temporal distributions produced for the Meloussa station. This figure indicates that $16 \%$ of the storms at the station deliver $70.3 \%$ of the total rainfall within the first $4 \mathrm{~h}$ of the storm.

In Figure 2, rainfall is represented as a cumulative precipitation depth of the total storm. This storm had some time increments duration slightly shorter than the nominal duration of 2, 6, and $24 \mathrm{~h}$. Therefore, an amount precipitation of $0 \mathrm{~mm}$ is introduced to lead the storm to the nominal duration [27]. 


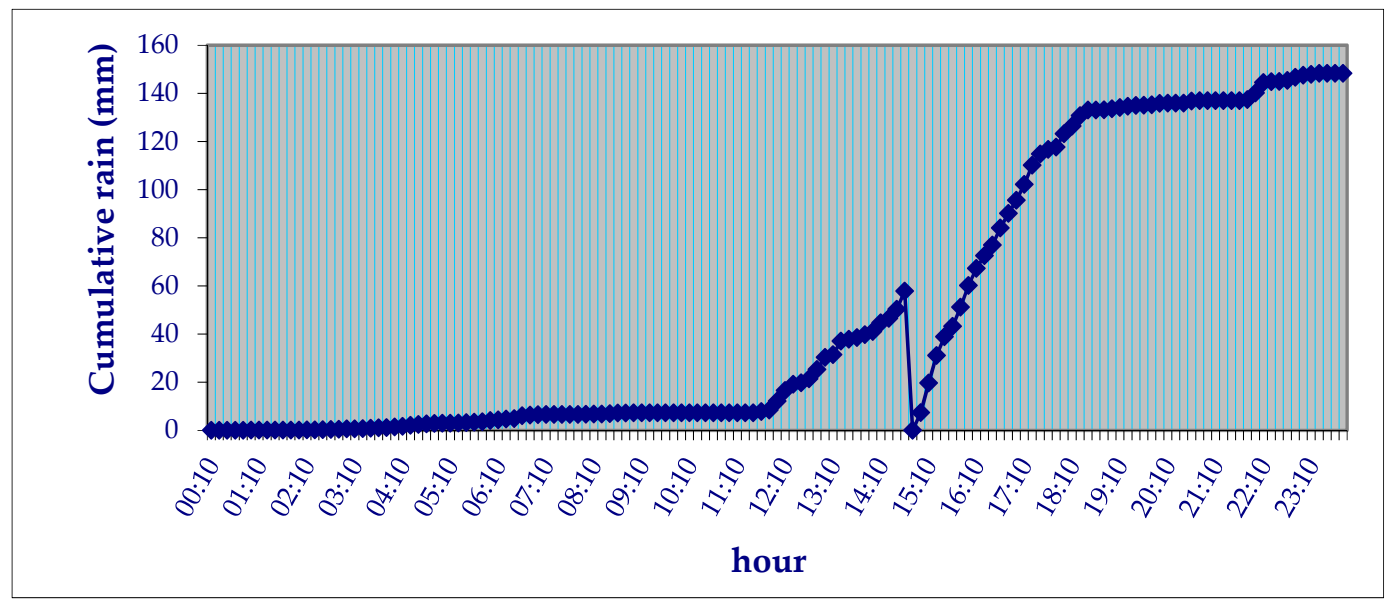

Figure 2. Cumulative precipitation depth of the total storm.

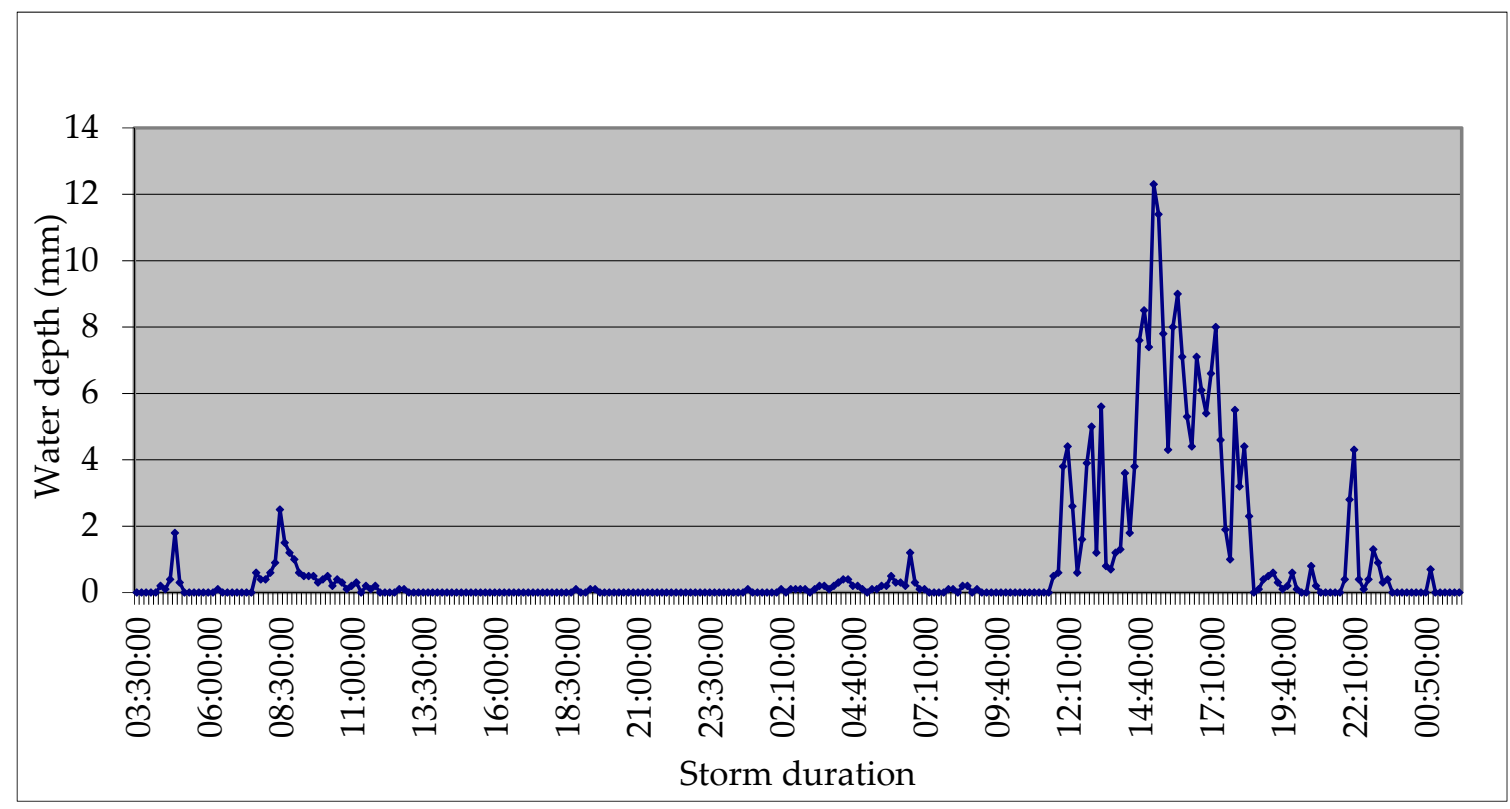

Figure 3. The observed hyetograph for the storm event taking place on the 23 October 2008 in the Melloussa station next to the KALAYA watershed.

\subsection{Instantaneous Flows Determination}

The instantaneous water levels for a number of non-flood were measured continuously at the KALAYA gauging station. However, due to a lack of additional data, the precision on this historical data set cannot be evaluated. In addition, the rating curve used to calculate the historical discharge series has not been archived. It was very important to trace after a few discharge measurements including the rating curve reflecting the water height rates. The detail of the daily instantaneous water levels recorded at the KALAYA rainfall station was obtained. These data were digitized since this document exists only on paper. Water levels reached various points during a few recorded rain events, which made it easy to determine the instantaneous flow rates as an indispensable element for calibration of the hydrological model. The observed instantaneous flows for the studied event are extracted from the rating curves developed by the water stage profile and discharges output.

Observed water levels and their correspondent calculated discharges in the 10 cross-sections references are available for the use in boundary conditions and calibration. The sections were surveyed by the "Direction Régionale de l'équipement de Tanger" (DIREN). Each cross section is characterized by a set of points surveyed perpendicularly to the main stream of the river and its bankfulls. Each 
point has a geographical position $(\mathrm{X}, \mathrm{Y})$, and altitude $(\mathrm{Z})$ and the datum used was Merchich north Morocoo with Lambert Conic Conformal projection.

Section controls, either natural or manufactured, are managed by hydraulic structures equations [28]. Hence, the instantaneous flows are related to river stages over a section of the stream bed by a hydraulic model. There are hydraulic structures, which drain water and, which, according to their dimensions, make it possible to obtain, with great precision, the value of instantaneous flow. However, discharges calculated by hydraulic methods are mainly managed by flow resistance coefficients [29-31]. However, the manning coefficients of the main stream and the banks remain uncertain and significantly influence water-level predictions [32-35].

In general and basic form, this equation is expressed below.

$$
\mathrm{Q}=\frac{1}{\mathrm{n}} \mathrm{AR}^{\frac{2}{3}} \mathrm{~S}^{\frac{1}{2}}
$$

where $\mathrm{n}$ is the Manning's roughness coefficient, $\mathrm{S}$ is the energy slope, $\mathrm{A}\left(\mathrm{m}^{2}\right)$ is the area of cross-section, and $\mathrm{R}(\mathrm{m})$ is the hydraulic radius. However, equation 2 is a simplification of the Manning equation, as it assumes that the conveyance function $\mathrm{AR}^{2 / 3}$ can be described by a simple power function of the water height, which is the case of a wide rectangular cross section.

This relationship can be established by various techniques of gauging field. Using control recoding of velocity values and evaluating the hydraulic structures section, stage-discharge transformation was completed by an empirical rating curve.

This method measures velocity directly in order to calculate stream flow. Both velocity and water depth measurements are taken at the same time and place in multiple locations across the channel, using a flow meter. The availability of the channel geometry, together with the observed maximum water levels, help develop a new rating curve and provides an in situ calibration for the KALAYA basin. Therefore, when this data is added to the high-resolution of the surveyed cross sections, it might provide a much better alternative when compared to the standard hydro-meteorological approaches [8].

However, due to a lack of additional data, the accuracy of this historical data set cannot be assessed. In addition, it is fairly unknown where and how historical flow velocity measurements were taken.

The hydrodynamic data is represented by 10 surveyed cross-sections containing the geometry, the velocity, and the observed stages. Their corresponding calculated discharges at KALAYA watershed are illustrated in Table 1.

Table 1. The hydrodynamic parameters calculated in 10 surveyed cross-sections at the KALAYA watershed.

\begin{tabular}{ccccccc}
\hline 9 Section & Period & $\begin{array}{c}\text { Velocity } \\
(\mathbf{m} / \mathbf{s})\end{array}$ & $\begin{array}{c}\text { Perimeter } \\
(\mathbf{m})\end{array}$ & Roughness & $\begin{array}{c}\text { Water Levels } \\
(\mathbf{m})\end{array}$ & $\begin{array}{c}\text { Discharge } \\
\left(\mathbf{m}^{\mathbf{3}} / \mathbf{s}\right)\end{array}$ \\
\hline 1 & $12 / 11 / 2012$ & 0.316 & 0.12 & 0.004 & 1.00 & 0.023 \\
2 & $11 / 03 / 2008$ & 0.303 & 0.08 & 0.004 & 1.10 & 0.040 \\
3 & $18 / 02 / 2008$ & 0.342 & 0.11 & 0.004 & 1.20 & 0.250 \\
4 & $22 / 01 / 2008$ & 0.381 & 0.08 & 0.004 & 1.33 & 0.750 \\
5 & $24 / 12 / 2007$ & 0.29 & 0.08 & 0.004 & 1.50 & 2.000 \\
6 & $11 / 06 / 2013$ & 0.168 & 0.07 & 0.004 & 1.80 & 5.900 \\
7 & $13 / 05 / 2013$ & 0.148 & 0.07 & 0.004 & 2.00 & 9.700 \\
8 & $11 / 02 / 2013$ & 0.353 & 0.12 & 0.004 & 2.20 & 14.500 \\
9 & $21 / 04 / 2008$ & 0.45 & 0.24 & 0.004 & 2.50 & 23.500 \\
10 & $09 / 12 / 2003$ & 1.813 & 1.18 & 0.004 & 2.66 & 28.971 \\
& & & & S. deviation & 0.62 & 10.55 \\
\hline
\end{tabular}

To construct a rating curve is to find a graphical representation of the stage-discharge relationship $(\mathrm{H} / \mathrm{Q})$ at a specific cross section. The rating curve is performed then by measuring the flow and the 
corresponding stage at appropriate times. This physical relationship between two characteristics of steady-state, flow on the one hand, and water level on the other hand, results when several correlation points of stage-discharge are established, which are to be concluded by adjusting the rating curve.

$$
\begin{gathered}
H=\frac{\sum_{i=1}^{n} h_{i} q_{i}}{\sum_{i=1}^{n} q_{i}} \\
Q=\sum_{i=1}^{n} q_{i}
\end{gathered}
$$

$\mathrm{q}_{\mathrm{i}}\left(\mathrm{m}^{3} / \mathrm{s}\right)=$ Rate of calculated flow width .

$\mathrm{h}_{\mathrm{i}}(\mathrm{m})=$ Corresponding side reference to the flow rate $\mathrm{q}_{\mathrm{i}}$.

$\mathrm{H}(\mathrm{m})=$ Gauge reference medium side $(\mathrm{m})$.

$\mathrm{Q}\left(\mathrm{m}^{3} / \mathrm{s}\right)=$ Total rate of flow corresponding to the medium side $\mathrm{H}$.

Errors occur when a single cross-section is used as a reference. For example, if the downstream level is lower than the gauging site, excessive flow could occur. Therefore, it would not be predicted by the adopted method. In fact, during the construction of the rating curve, the point beyond which a small increase in water height corresponded to a greater increase in flow in order to achieve a better possible correlation between the stages and discharges. In view of the gauges availability, the most suitable point corresponds to a water depth of $2.66 \mathrm{~m}$, which corresponds to the value $28.971 \mathrm{~m}^{3} / \mathrm{s}$ of flow.

The measured stage-discharge points are then adjusted to a polynomial function, which makes it easy to transform the recorded water level into discharge time series. Lastly, a positive linear correlation was found (Pearson's correlation coefficient $r$ of 1 ) between the water level (23-24 October) and the correspondent discharge values (Figure 4).

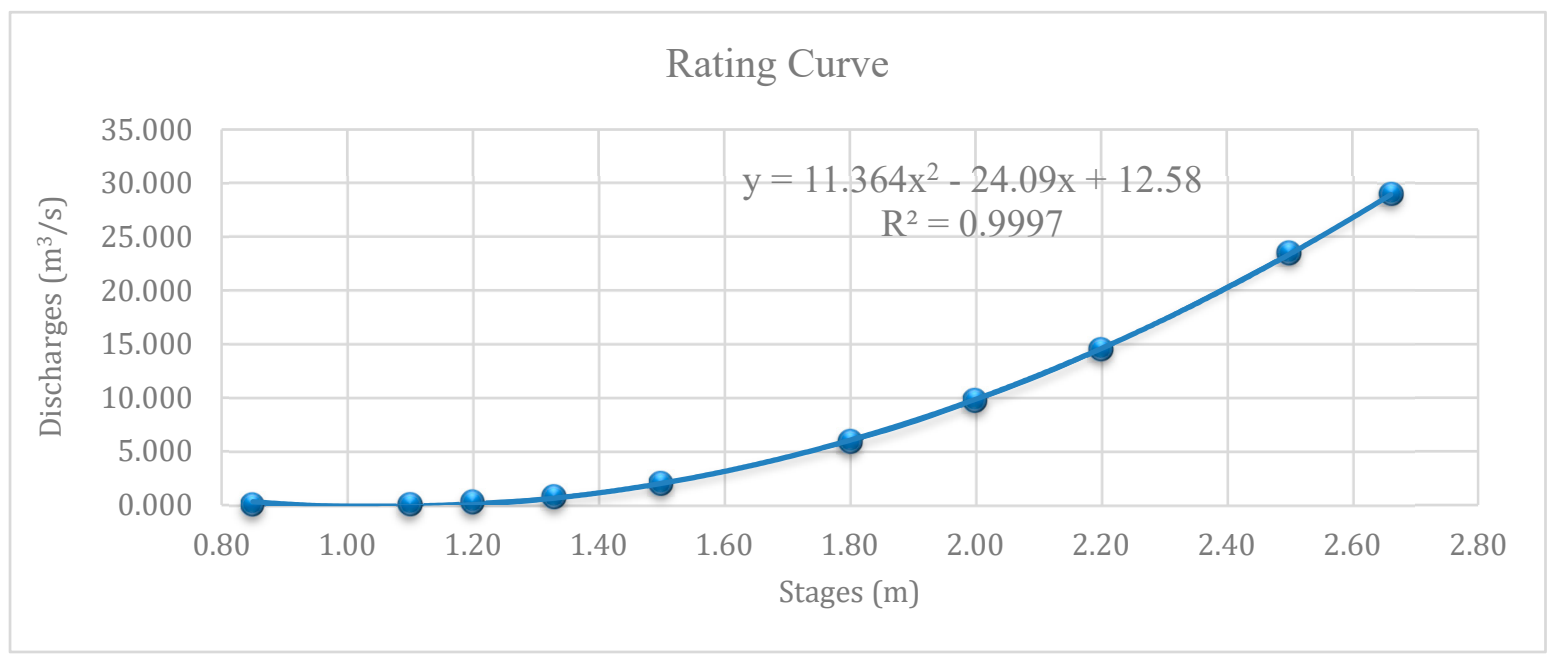

Figure 4. Rating curve at the KALAYA gauging station.

\section{Results}

\subsection{HEC-HMS Modeling}

Actually, the reconstruction of historical floods can help improve the forecasting ability and, thus, the prevention capacity, which is presently based, in most of the cases, on very short gauging data series. The runoff corresponding to the watershed of the KALAYA basin was calculated through the SCS CN loss method and the SCS Unit Hydrograph transform method. The meteorological data used is based on the gauging station implemented at the downstream on 23 October 2008 until 24 October 2008. 
This historical storm event occurred due to the $215 \mathrm{~mm}$ of precipitation during a three-hour rain event. The data were inserted into the model through the use of the specified hyetograph method. HEC-HMS (Hydrologic Engineering Center Hydrologic Modeling System) model was developed by the US Army Corps of Engineers and has been used for many hydrological simulations. The HEC-HMS model can be used to analyze urban flooding, flood frequency, flood warning system planning, reservoir spillway capacity, stream restoration, etc.

In order to simulate the hydrological behavior of the basin of KALAYA, it required going through the same process used in a previous study at the same basin [23]. Delineate the basin, extract the physical and morphological settings, and generate the soil map and land used to develop the CN map (Table 2). These data is considered the main input for the hydrological simulation KALAYA. Meanwhile, the model consists of a rainfall-runoff model (HEC-HMS) that converts precipitation excess to channel runoff based on the HEC-HMS-derived hydrographs [36].

To calibrate the rainfall-runoff model in the KALAYA watershed, the method adopted is the SCS Curve Number. In particular, this method calculates incremental precipitation during a storm by recalculating the infiltration volume at the end of each time interval. The second approach was the application of the SCS Unit Hydrograph method as a transformational method. In this case, while the specified Hyetograph in the meteorological model is used, the hydrograph is scaled by the lag time in order to produce the unit hydrograph.

Table 2. Hydrologic characteristics of the KALAYA watershed.

\begin{tabular}{cccccc}
\hline \multicolumn{3}{c}{ Physical Components } & \multicolumn{2}{c}{ Loss Method } & Transform Method \\
\hline Surface $\left(\mathbf{K m}^{2}\right)$ & Slope (\%) & $\begin{array}{c}\text { Perimeter } \\
(\mathbf{K m})\end{array}$ & $\begin{array}{c}\text { Initial Abstraction } \\
(\mathbf{m m})\end{array}$ & Average CN & Lag Time (hours) \\
\hline 37.3 & 8.47 & 13.205 & 8 & 82.07 & 2.082715 \\
\hline
\end{tabular}

The second task consists in inputting the instantaneous rain flow from the observed water-stage and the instantaneous rainfall recorded in order to represent the observed rainfall-runoff series trough HEC-HMS. Preliminary tests with the calibrated rainfall-runoff model reveal that the simulated peak discharge $\left(322.8 \mathrm{~m}^{3} / \mathrm{s}\right)$ of the storm event does not match the peak discharge value of $450 \mathrm{~m}^{3} / \mathrm{s}$ (Table 2). Hence, the rainfall-runoff model will only be run with the reference time periods and peak discharge that exceed $450 \mathrm{~m}^{3} / \mathrm{s}$. Below, the results obtained from the simulation of the storm event of 23 October 2008.

Figure 5 shows the variation of the hydrograph (instantaneous rainfall based on instantaneous flow rates). The runoff is characterized in blue while the infiltrated part is characterized by red.

Based on the comparison between the observed hydrograph (black curve) and the simulated hydrograph (blue curve), we can conclude that peak flows occurred in different times. The curve displays a very high intensity at the end of the storm. In addition, the discharge volumes do not seem to be captured well with the simulation. The simulated flow has a volume greater than that observed. It becomes clear that the model parameters need to be calibrated. The simulated volume is $16 \%$ smaller than the observed volume. The simulated hydrograph still produces a smaller peak discharge and the time-to-peak is $2 \mathrm{~h}$ ahead of $4620 \mathrm{~s}$. Another result worth of mention is that the difference between the observed total rainfall hyetograph and the excess rainfall hyetograph are abstractions or losses. In this case, and with a configuration of $\mathrm{CN}=82$ and a Lag time $=125 \mathrm{~min}$, the simulated peak discharge is around $40 \%$ less than the observed peak discharge. The simulated peak flow is around 1.5 times the observed one. 

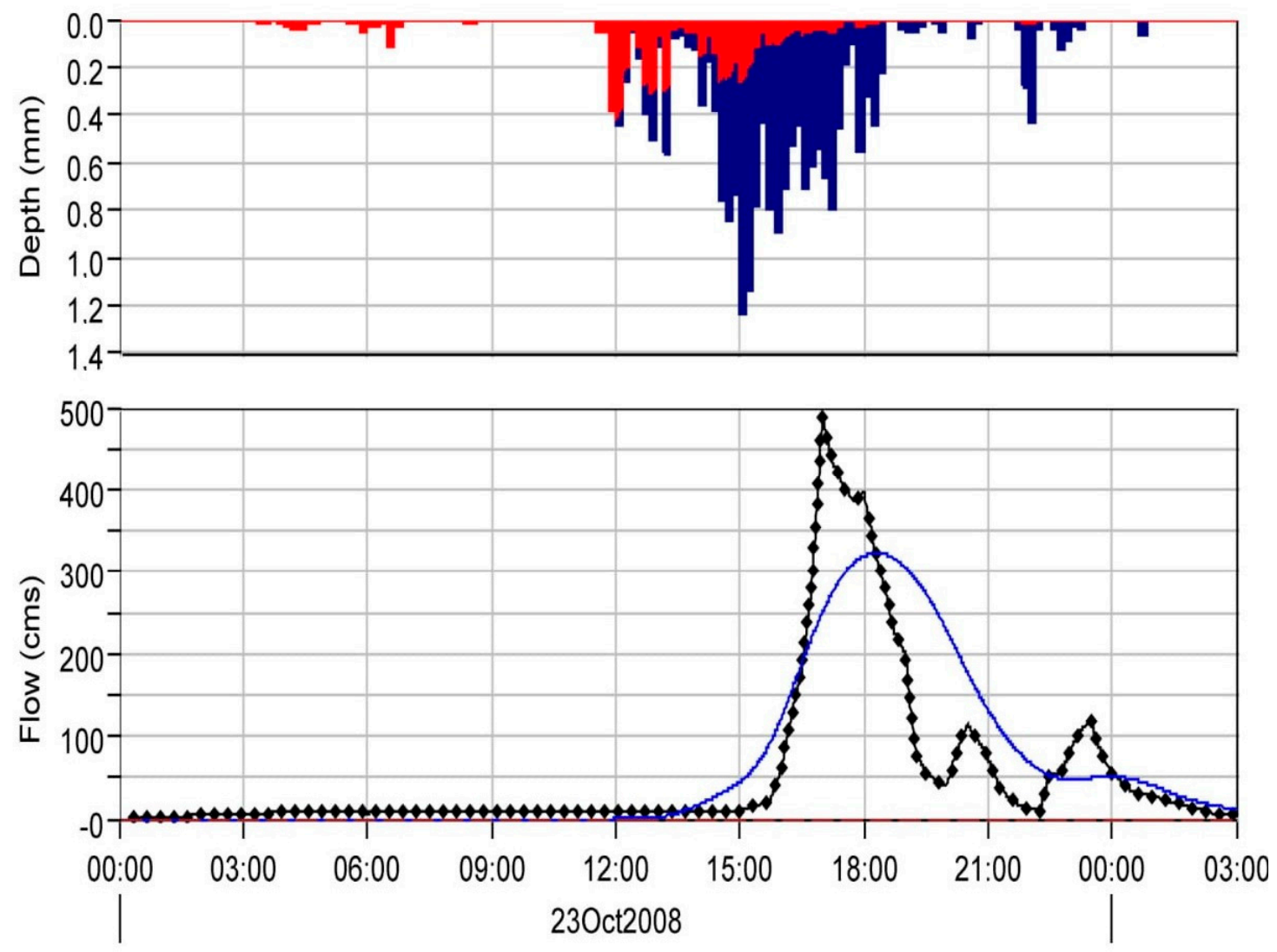

Figure 5. The simulated and observed hydrogram for the storm event on 23 October 2008.

\subsection{Calibration Approch}

The objective functions measure the variation between an observed and simulated hydrograph [37]. Optimization is a form of estimating parameters that adjust the gaps so that the simulated results correspond more closely to the observed data. HEC-HMS performs parameter optimization by providing different objective functions. The simulation of the control specification model defines when each simulation starts and ends, and also defines the time frame that HEC-HMS will be used in the analysis. Calibration was carried out for the period from 23 October 2008 at 00:00 to 24 October 2008 between 00:00 and 03:00 with a time step of $10 \mathrm{~min}$. Precipitation and flow data were placed in the data module. Basin parameters such as slope, area, time of concentration, the lag time and $\mathrm{CN}$ were introduced as input parameters of the HEC-HMS Rainfall-Runoff model. The parameters are identified through optimization, which tries to minimize the root mean square error between observed and simulated discharge at the river downstream. The parameter ranges must be constrained and the final values should be checked to verify its accuracy. In our case, the objective function used for calibration of the simulation is the "Percent Peak Error".

$$
\mathrm{PPE}=\frac{\mathrm{x}_{\mathrm{obs}, \mathrm{i}}-\mathrm{x}_{\text {model }, \mathrm{i}}}{\mathrm{x}_{\mathrm{obs}, \mathrm{i}}} \times 100
$$

where $x_{o b s, i}$ is the observed rate, while $X_{\text {model }}$ is the simulated flow at time $i$.

During the calibration, the parameters to be optimized, in particular the curve number and initial abstraction, will be applied across the KALAYA watershed. The process was iterative, trying different peak discharge attempts until the modeled peak discharge and the observed one are close enough. Furthermore, the global model with its initial settings was adjusted during the optimization approach in order to make the simulated hydrograph and the observed one compatible, as similar as possible, 
for the studied storm event. The simulated and the observed hydrographs at the KALAYA rainfall station are shown in Figure 6 and the results of the model calibration are shown in Tables 3 and 4.

\section{Hydrograph Comparison}

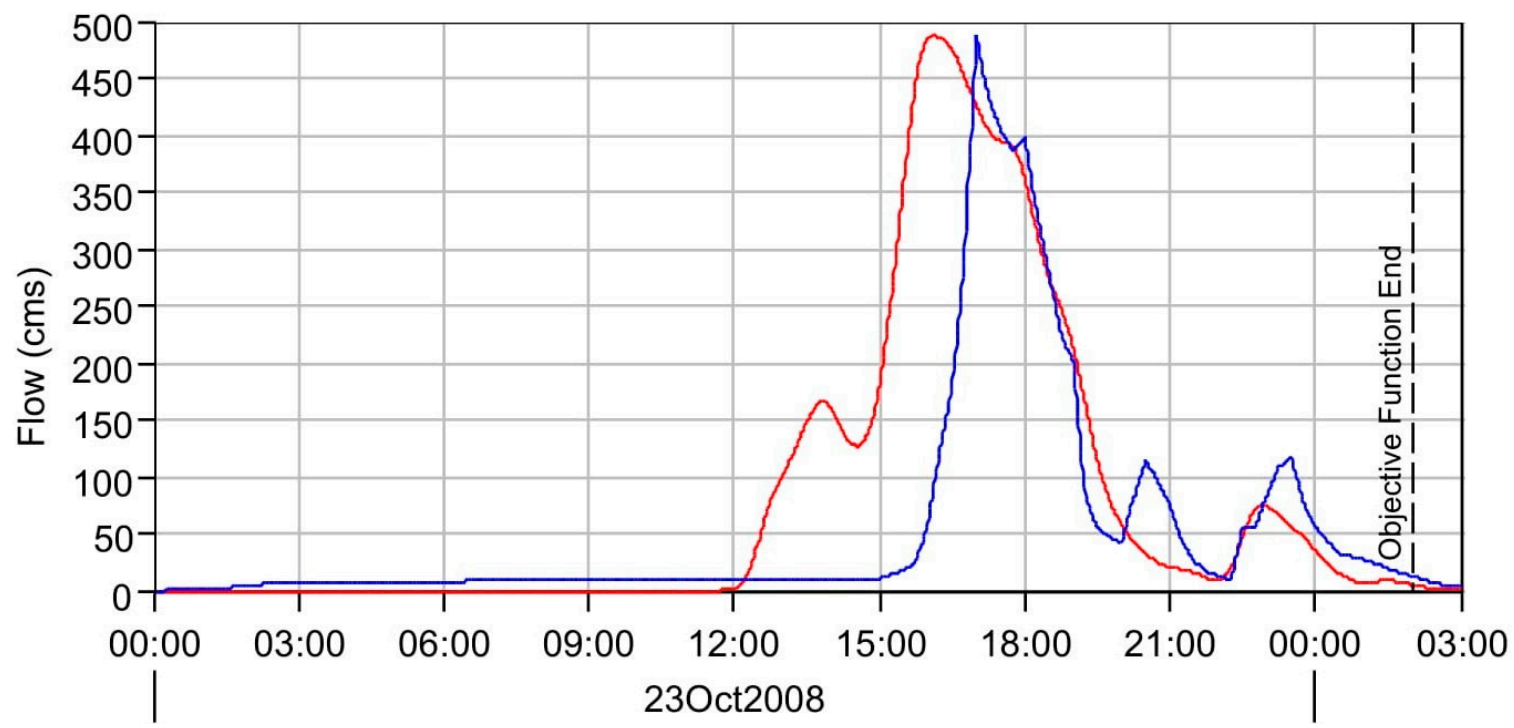

Figure 6. The observed and simulated hydrograph after calibration.

Table 3 shows an optimization summary comparing simulated and Table 4 shows objective function sensitivity for the calibrated values of initial abstraction, curve number, and the Table 5 shows the observed and the simulated discharge and volume.

Table 3. Simulation summary results for the KALAYA watershed.

\begin{tabular}{|c|c|c|c|c|}
\hline Bassin & Drainage Area $\mathrm{Km}^{2}$ & Peak Discharge $\mathrm{m}^{3} / \mathrm{s}$ & Peak Time & Volume $\left(1000 \mathrm{~m}^{3}\right)$ \\
\hline KALAYA & 37 & 321.9 & $\begin{array}{c}23 \text { October 2008, } \\
18: 18\end{array}$ & 5553.8 \\
\hline
\end{tabular}

Table 4. Settings before and after calibration Add units.

\begin{tabular}{cccc}
\hline Parameter & Initial Value & Optimized Value & Objective Function Sensitivity \\
\hline Curve Number & 82 & 89.162 & 7.68 \\
Initial Abstraction (mm) & 8 & 7.3789 & -43.47 \\
SCS Lag (min) & 124.9629 & 36.286 & -30.05 \\
\hline
\end{tabular}

Table 5. Values of the simulated and the observed peak discharge of the studied event.

\begin{tabular}{ccccc}
\hline Measure & Simulated & Observed & Difference & Percent Difference \\
\hline Volume & 5593.4 & 5193.3 & 400.1 & 7.42 \\
Peak Flow & 321.9 & 486.7 & 164 & 40.52 \\
Time of Peak & 23 October 2008, 16:07 & 23 October 2008, 17:00 & & \\
Time of Center of Mass & 23 October 2008, 17:03 & 23 October 2008, 17:03 & & \\
\hline
\end{tabular}

However, as shown in the hydrograph, increasing flood peak typically occurred for a short period of time (short duration corresponds to a high volume). By analyzing the sequence of the 23 October 2008 event, the calibration shows that the simulated hydrograph peak flow is better and has the same tendency as that of the observed flow hydrograph (Figure 6). The objective function of the peak flow is to help perfectly recreate the peak flow hydrograph. Meanwhile, the calibration fails to follow the 
tendency of the simulated volume. However, based on the results, one can notice an overestimation of the simulated volume. This can be explained by the fact that the flow rates tend to rise to a peak but are delayed from the observed peak rates. However, globally, the model recreates the behavior of the watershed.

\section{Conclusions}

The stage-discharge relationship is an approximate method employed for estimating discharge in rivers. The stage-discharge relationship at a gauging station is usually represented by a rating curve determined from a series of stage-discharge measurements. The simulated values of the discharge and the volume values were calibrated using water level data for 10 points. The observed water level values agreed closely with the observed peak discharges of the flood events value in the studied catchment $\left(\mathrm{r}^{2}=0.9997\right)$.

Regarding the calibration process, the peak flow of $486.7 \mathrm{~m}^{3} / \mathrm{s}$ was used to improve the difference between the simulation and the observation parameters. Several values of the water levels and their corresponding discharges were used to determine the rating curve in order to optimize the simulated hydrograph.

Modeling the watershed has been implemented with the Soil Conservation Service (SCS) using the HEC-HMS model. Initial simulation results of the hyetrograph showed that there is a difference between measured and simulated peak flows. This difference is in a range of a $40.52 \%$ acceptable error, to mitigate the difference, the rainfall-runoff model calibration was performed with lag time, initial abstraction, and curve number sensitive parameters. The observed instantaneous water levels and rainfall from two gauging stations for an extreme storm event were used to calibrate and the final values of the input parameters and considered valid because of the non-obtaining of other events. The hydrologic model and calibrated parameters would then be used to simulate future scenarios within the KALAYA watershed and the neighboring basins. We suggest that, after identifying the key calibrated parameters ( $\mathrm{CN}$, Ia, and Lag time), further simulations should be carried out to reduce the model error by using more recorded flood events data.

Author Contributions: I.K. ran the numerical simulations and methodology; M.A. review and editing; A.B and resources and validation; A.H.A. supervision and project administration. All the authors contributed to the discussion of the results; I.K. wrote the paper that was then revised by all the authors.

Funding: This research received no external funding.

Conflicts of Interest: The authors declare no conflict of interest.

\section{References}

1. Werren, G.; Lasri, M. Cartographie du Danger D'inondation. In Guide Pratique Pour L'application de la Méthode Suisse au Maroc; université de Lausanne and université Sidi Mohamed Ben Abdellah: Fès, Maroc, 2014.

2. Norbiato, D.; Borga, M.; Sangati, M.; Zanon, F. Regional frequency analysis of extreme precipitation in the eastern Italian Alps and the August 29, 2003 flash flood. J. Hydrol. 2007, 345, 149-166. [CrossRef]

3. Creutin, J.D.; Borga, M. Radar hydrology modifies the monitoring of flashflood hazard. Hydrol. Process. 2003, 17, 1453-1456. [CrossRef]

4. Koutroulis, A.G.; Tsanis, I.K. A method for estimating flash flood peak discharge in a poorly gauged basin: Case study for the 13-14 January 1994 flood, Giofiros basin, Crete, Greece. J. Hydrol. 2010, 385, 150-164. [CrossRef]

5. Lumbroso, D.; Gaume, E. Reducing the uncertainty in indirect estimates of extreme flash flood discharges. J. Hydrol. 2012, 414-415, 16-30. [CrossRef]

6. Buchanan, T.J.; Somers, W.P. Discharge Measurements at Gaging Stations; Techniques of Water-Resources Investigation of the United States Geological Survey: Reston, VA, USA, 1969.

7. Olson, S.A.; Norris, J.M. U.S. Geological Survey Streamgaging; U.S. Geological Survey Fact Sheet: Reston, VA, USA, 2005; pp. 2005-3131. 
8. Conesa-Garcia, C.; Caselles-Miralles, V.; Sanchez, J.M.; Garcia-Lorenzo, R. Hydraulic Geometry, GIS and Remote Sensing, Techniques against Rainfall-Runoff Models for Estimating Flood Magnitude in Ephemeral Fluvial Systems. Remote Sens. 2010, 2, 2607-2628. [CrossRef]

9. Nouh, M. Effects of rainfall runoff model assumptions on optimal storm sewer system design. Arab. J. Sci. Eng. 1985, 12, 19-35.

10. Huff, F. Time distribution of rainfall in heavy storms. Water Resour. Res. 1967, 3, 1007-1019. [CrossRef]

11. Gaume, E.; Bain, V.; Bernardara, P.; Newinger, O.; Barbuc, M.; Bateman, A.; Blaškovicová, L.; Blöschl, G.; Borga, M.; Dumitrescu, A.; et al. A compilation of data on European flash floods. J. Hydrol. 2009, 367, 70-78. [CrossRef]

12. Graef, F.; Haigis, J. Spatial and temporal rainfall variability in the Sahel and its effects on farmers' management strategies. J. Arid Environ. 2001, 48, 221-231. [CrossRef]

13. Ghimire, B.; Reddy, M.J. Development of stage-discharge rating curve in river using genetic algorithms and model tree. In Proceedings of the International Workshopadvances in Statistical Hydrology, Taormina, Italy, 23-25 May 2010.

14. Pan, F.; Wang, C.; Xi, X. Constructing river stage-discharge rating curves using remotely sensed river cross-sectional inundation areas and river bathymetry. J. Hydrol. 2016, 540, 670-687. [CrossRef]

15. Herschy, R.W. Streamflow Measurement; Elsevier Applied Science Publishers: New York, NY, USA, 1985.

16. Dottori, F.; Martina, M.L.V.; Todini, E. A dynamic rating curve approach to indirect discharge measurement. Hydrol. Earth Syst. Sci. 2009, 13, 847-863. [CrossRef]

17. Jothityangkoon, C.; Hirunteeyakul, C.; Boonrawd, K.; Sivapalan, M. Assessing the impact of climate and land use changes on extreme floods in a large tropical catchment. J. Hydrol. 2013, 490, 88-105. [CrossRef]

18. Goodrich, D.; Woolhiser, D.; Unkrich, C. Rainfall-sampling impacts on runoff. In Hydraulics/Hydrology of Arid Lands; French, R.H., Ed.; American Society of Civil Engineers: New York, NY, USA, 1990; pp. 519-524.

19. Mosley, M.P.; McKerchar, A.I. Streamflow, Handbook of Hydrology; Maidment, D.R., Ed.; McGraw-Hill: New York, NY, USA, 1992.

20. Leopold, L.B.; Wolman, M.G.; Miller, J.P. Fluvial Processes in Geomorphology; W.H. Freeman: San Francisco, CA, USA, 1964.

21. USDA. Summary Report: National Resources Inventory (Revised December 2001); US Department of Agriculture, Natural Resource Conservation Service: Washington, DC, USA, 1997.

22. Ramirez, J.A. Prediction and Modeling of Flood Hydrology and Hydraulics. In Chapter 11 of Inland Floods Hazards: Human, Riparian and Aquatics Communities; Wohl, E., Ed.; Cambridge University Press: Cambridge, UK, 2000.

23. Khaddor, I.; Alaoui, A.H. Production of a Curve Number map for Hydrological simulation-Case study: Kalaya Watershed located in Northern Morocco. Int. J. Innov. Appl. Stud. 2014, 9, 1691-1699.

24. Cunderlik, J.M.; AndSimonovic, S.P. Inverse flood risk modeling under changing climatic conditions. Hydrol. Process. 2007, 21, 563-577. [CrossRef]

25. McColl, C.; Aggett, G. Land-use forecasting and hydrologic model integration for improved land-use decision support. J. Environ. Manag. 2007, 84, 494-512. [CrossRef] [PubMed]

26. Guo, J.C.Y.; Hargadin, K. Conservative Design Rainfall Distribution. J. Hydrol. Eng. 2009, 14. [CrossRef]

27. Al-Rawas, G.A.; Valeo, C. Characteristics of rainstorm temporal distributions in arid mountainous and coastal regions. J. Hydrol. 2009, 376, 318-326. [CrossRef]

28. Casas, A.; Benito, G.; Thorndycraft, V.R.; Rico, M. The topographic data source of digital terrain models as a key element in the accuracy of hydraulic flood modelling. Earth Surf. Process. Landf. 2006, 31, 444-456. [CrossRef]

29. Vidal, J.-P.; Moisan, S.; Faure, J.-B.; Dartus, D. River model calibration, from guidelines to operational support tools. Environ. Model. Softw. 2007, 22, 1628-1640. [CrossRef]

30. Morvan, H.; Knight, D.; Wright, N.; Tang, X.; Crossley, A. The concept of roughness in fluvial hydraulics and its formulation in 1D, 2D and 3D numerical simulation models. J. Hydraul. Res. 2008, 46, 191-208. [CrossRef]

31. Paarlberg, A.J.; Dohmen-Janssen, C.M.; Hulscher, S.J.M.H.; Termes, P.; Schielen, R. Modelling the effect of time-dependent river dune evolution on bed roughness and stage. Earth Surf. Process. Landf. 2010, 35, 1854-1866. [CrossRef]

32. World Meteorological Organization. Manual on Stream Gauging, Volume II-Computation of Discharge; WMO-No. 1044; World Meteorological Organization: Geneva, Switzerland, 2010; ISBN 978-92-63-11044-2. 
33. Van der Klis, H. Uncertainty Analysis Applied to Numerical Models of River Bed Morphology. Ph.D. Thesis, University of Delft, Delft, The Netherlands, 2003.

34. Paarlberg, A.J. Modelnauwkeurigheid en-Onzekerheden van in Nederland Toegepaste Hydraulische Modellen: Verslag van Interviews met Waterbeheerders en Modelexperts (in Dutch); Civil Engineering and Management Research Report 2007R-001/WEM-001; University of Twente: Enschede, The Netherlands, 2007.

35. Warmink, J.J.; Booij, M.J.; van der Klis, H.; Hulscher, S.J.M.H. Uncertainty in water level predictions due to various calibrations. In Proceedings of the CAIWA 2007, Basel, Switzerland, 12-15 November 2007; pp. 1-18.

36. United States Army Corp of Engineering (USACE). Hydrologic Modeling System HEC-HMS; USACE: Washington, DC, USA, 2000.

37. Scharffenber, W.A.; Fleming, M.J. Hydrological Modeling System HEC-HMS User's Manual; United States Army Corps of Engineers: Davis, CA, USA, 2010.

(c) 2019 by the authors. Licensee MDPI, Basel, Switzerland. This article is an open access article distributed under the terms and conditions of the Creative Commons Attribution (CC BY) license (http://creativecommons.org/licenses/by/4.0/). 